\title{
Lipid and Fatty Acids Accumulation Features of Entomoneis cf. paludosa during Exponential and Stationary Growth Phases in Laboratory Culture
}

\author{
Yekaterina Bedoshvili ${ }^{1, *}$, Yulia Podunay ${ }^{2}$ (D), Alyona Nikonova ${ }^{1}$, Artyom Marchenkov ${ }^{1}$, Elvira Bairamova ${ }^{1}$, \\ Nikolai Davidovich ${ }^{2}$ and Yelena Likhoshway ${ }^{1}$ (D) \\ 1 Department of Cell Ultrastructure, Limnological Institute, Siberian Branch of the Russian Academy of \\ Sciences, 664033 Irkutsk, Russia; alenaxis@list.ru (A.N.); marchenkov.am@gmail.com (A.M.); \\ bairamovaelvira@gmail.com (E.B.); likhoshway@mail.ru (Y.L.) \\ 2 Karadag Scientific Station-Nature Reserve of RAS—Branch of IBSS, 298188 Feodosia, Russia; \\ grab-ua@yandex.ru (Y.P.); nickolaid@mail.ru (N.D.) \\ * Correspondence: bedoshvilied@list.ru
}

\section{check for}

updates

Citation: Bedoshvili, Y.; Podunay, Y.; Nikonova, A.; Marchenkov, A.; Bairamova, E.; Davidovich, N.; Likhoshway, Y. Lipid and Fatty Acids Accumulation Features of Entomoneis cf. paludosa during Exponential and Stationary Growth Phases in Laboratory Culture. Diversity 2021 13, 459. https://doi.org/10.3390/ d13100459

Academic Editor: Stuart Donachie

Received: 30 July 2021

Accepted: 16 September 2021

Published: 23 September 2021

Publisher's Note: MDPI stays neutral with regard to jurisdictional claims in published maps and institutional affiliations.

Copyright: (c) 2021 by the authors. Licensee MDPI, Basel, Switzerland. This article is an open access article distributed under the terms and conditions of the Creative Commons Attribution (CC BY) license (https:/ / creativecommons.org/licenses/by/ $4.0 /)$.

\begin{abstract}
Diatoms are capable of accumulating substantial amounts of triacylglycerides in their cells, which differ in the composition of fatty acids depending on the conditions of cultivation, making them attractive subjects in biotechnology. In the present study, we characterized the structural features of lipid bodies in the diatom Entomoneis cf. paludosa (W. Smith) Reimer strain 8.0727-B and revealed the peculiarities of fatty acid composition in cultures during the stationary and exponential growth phases. Laser scanning confocal microscopy revealed an increased number of lipid bodies in the cytoplasm during the stationary phase of culture growth. Electron microscopy of ultrathin sections showed that an extreme increase in the number and size of plastoglobules in the cells occurs in the stationary phase of culture growth. The gas chromatography with mass spectrometric detection method revealed differences in the fatty acid composition depending on the growth phase. The studied strain can be recommended as a source of hexadecanoic and octadecanoic fatty acids from the culture during the stationary growth phase, as well as eicosapentaenoic fatty acid from the culture during the exponential growth phase.
\end{abstract}

Keywords: diatoms; lipid bodies; plastoglobules; chloroplast ultrastructure; fatty acid composition

\section{Introduction}

Diatoms are one of the largest groups of Heterokonta organisms that dominate in the oceans. Due to their ability to fix a considerable amount of atmospheric carbon (over $20 \%$ of primary production in the world oceans) and its global importance in the silicon cycle [1], diatoms attract the attention of specialists in various fields. In the cells of diatoms, assimilated carbon accumulates as triacylglycerides (TAGs), which constitute between $25 \%$ [2] and 50\% [3] of their dry weight. Diatoms can be a potential source of both biofuel and polyunsaturated $\omega-3, \omega-6$ fatty acids, vitamins, and other substances $[4,5]$.

Diatoms, like other microalgae, accumulate neutral lipids (TAGs) under stressful conditions [6,7], especially a deficiency of nitrogen [8], phosphorus [9], and silicon [10]. The fatty acid composition of diatom TAGs can vary depending on the cultivation conditions [11]. TAGs of diatoms accumulate in special lipid bodies, which are also repositories of other biological macromolecules and various biologically active substances [12]. The location of lipid bodies in the cytoplasm and their quantity can be species-specific [12].

Plastoglobules, lipoprotein particles in the chloroplast stroma, are other sites of lipid accumulation. These particles were discovered as early as 1963 [13] and are found in many autotrophic organisms [14]. Plastoglobules are highly osmiophilic structures because of the unsaturated fats they contain [13]. Plastoglobules are enriched in free fatty acids, 
carotenoids, tocopherols, and plastoquinones and can change their size and quantity in response to stressful conditions [14-17]. In diatoms, plastoglobules have long been known as osmiophilic globules [18]. Apart from a publication that appeared in 2016, these structures in diatoms have been overlooked by researchers [19].

In connection with the development of biotechnological industries, the study of the ultrastructure and composition of various microalgae, which produce a wide range of biologically active substances, precursors, etc., is currently an urgent task. In this work, a comparative study was conducted on the ultrastructure of lipid bodies and the fatty acid composition of the diatom Entomoneis cf. paludosa (W. Smith) Reimer (strain 8.0727B) in the laboratory culture during the stationary and exponential growth phases. This species previously attracted the attention of researchers as an object of the study of the sexual reproduction of diatoms [20] and as a source of fatty acids (FAs) [11]; however, its ultrastructure remains unexplored.

\section{Materials and Methods}

\subsection{Algae Cultivation}

Entomoneis cf. paludosa (W. Smith) Reimer (strain 8.0727-B) was obtained from the Collection of Diatoms of Karadag Scientific Station (southeast coast of the Crimean Peninsula), named after T.I. Vyazemsky [21]. The cells were grown in a medium that was similar in composition to the Enriched Seawater, Artificial Water (ESAW) medium [22] with modifications [23] and diluted with distilled water to the required salinity $(18 \%)$ at $20{ }^{\circ} \mathrm{C}$ and under native illumination. To obtain growth curves, cells were grown in the 96-well plates over 62 days according to the method described earlier [24]. The total number of cells was counted in wells with a volume of $200 \mu \mathrm{L}$ in four replicates on days $1,4,5,8,11,20,30,45$, and 62 of growth.

For microscopy analysis, cells were grown in 0.1-0.2 L glass flacks, as described above, for 14 days (the exponential stage of growth) and 62 days (the stationary stage of growth). Upon inoculation, the cell density was $127 \pm 14.35$ cells $/ \mathrm{mL}$. For fatty acid analysis, the cells were cultivated during periods of 14 and 62 days in 10L glass bottles. The cells were filtered through $2.5 \mu \mathrm{m}$ membrane filters and centrifuged at $2500 \mathrm{rpm}$ for $20 \mathrm{~min}$.

\subsection{Microscopy}

To visualize the chloroplasts, unfixed cells were studied with a laser-scanning microscope LSM 710 (Zeiss) equipped with a Plan-Apochromat $63 \times / 1.40$ Oil DIC M27 immersion lens (Zeiss). Chloroplast autofluorescence was excited with a $561 \mathrm{~nm}$ laser; emission was registered in the range of $650-723 \mathrm{~nm}$. For visualization of lipid bodies, cells were stained with BODIPY 505/515 (Thermo Fisher Scientific, Waltham, MA, USA) according to the protocol proposed by the manufacturer. In brief, the working stain solution BODIPY 505/515 (0.5 mM) was added to the cells in the medium to a final concentration of $2 \mu \mathrm{M}$. After $30 \mathrm{~min}$, the cells were washed with $0.1 \mathrm{M}$ phosphate buffer ( $\mathrm{pH}$ 7.4) and fixed with $4 \%$ paraformaldehyde solution. Samples were embedded in Mowiol ${ }^{\mathrm{TM}}$ and examined with an LSM 710 microscope. The fluorescence of BODIPY 505/515 was excited with a laser at $488 \mathrm{~nm}$; emission was registered in the range of $476-556 \mathrm{~nm}$. All images were obtained with ZEN 2010 software (Zeiss). Three-dimensional reconstructions were obtained for cells located relatively horizontally from 120 optical sections (each with a thickness on the z-axis of $0.12 \mu \mathrm{m})$.

For transmission electron microscopy, cells were fixed, and sections were made as described previously [25]. Preparations were examined in a Leo 906 E transmission electron microscope (Carl Zeiss, Jena, Germany) at $80 \mathrm{kV}$ and imaged with a MegaView II digital camera (Olympus Soft Imaging Solutions, Münster, Germany).

\subsection{Fatty Acid Analysis}

The sample humidity was calculated according to gravity measurements. The Folch mixture (chloroform-nethanol, 2:1, by volume) was used to extract lipids from repli- 
cate samples $(\sim 0.02 \mathrm{~g}$ of wet weight). The samples were placed in plastic $2 \mathrm{~mL}$ tubes, and fatty acids were extracted by shaking and sonication $(1.2 \mathrm{~mL} \times 3 \times 5 \mathrm{~min})$ using a $50 \mathrm{~Hz}$ ultra-sonication bath. The three extracts were combined in glass centrifuge test-tubes. The distilled water $(1.2 \mathrm{~mL})$ was added to the extract. The mixture was emulsified and centrifuged at $13,000 \times g \mathrm{rpm}$ for $3 \mathrm{~min}$. The chloroform extracts were transferred to $10 \mathrm{~mL}$ glass vials, and the solvent was evaporated using an argon stream.

Fatty acid methyl esters (FAMEs) were derived through the acid esterification of fatty acids as described earlier [26]. First, $4.5 \mathrm{~mL}$ of $2 \% \mathrm{H}_{2} \mathrm{SO}_{4}$ solution in methanol was added to the dry fraction. The bottles were covered with aluminum foil caps and kept for $1.5 \mathrm{~h}$ at $55^{\circ} \mathrm{C}$. Next, $0.8 \mathrm{~mL}$ of $\mathrm{n}$-hexane was added to the FAME solutions, and the samples were cooled to room temperature. FAMEs were extracted twice with n-hexane ( $3 \mathrm{~mL} \times 2 \mathrm{~min}$ ). Extracts were dried with anhydrous $\mathrm{Na}_{2} \mathrm{SO}_{4}$ and concentrated using an argon stream to $\sim 1 \mathrm{~mL}$ volume. An internal standard ( $1 \mathrm{mg} \mathrm{L}^{-1}$ of dodecyl ether solution in n-hexane) was added.

Qualitative analysis of FAMEs by gas chromatography with mass spectrometric detection (GC-MS) was carried out using an Agilent 6890B GC System coupled to a 7000C GC/MS Triple Quad mass spectrometer (Agilent, Santa Clara, CA, USA). The conditions were as follows: injector temperature, $290{ }^{\circ} \mathrm{C}$; quadrupole temperature, $150{ }^{\circ} \mathrm{C}$; injection into the column of $2 \mu \mathrm{L}$ of sample in the splitless regime. FAME chromatogram peaks were identified by retention times and their full mass spectra using the NIST Mass Spectral Search Program for the NIST/EPA/NIH Mass Spectral Library software (V. 2.2).

Quantitative analysis of FAMEs was carried out using a Shimadzu GC-2010 Plus GC (Shimadzu, Kyoto, Japan) coupled to a flame ionization detector (FID). The conditions were as follows: injector and FID temperature, $340{ }^{\circ} \mathrm{C}$; injection into the column of $2 \mu \mathrm{L}$ of sample in the splitless regime; pressure, $75.5 \mathrm{kPa}$; column flow rate, $0.88 \mathrm{~mL} \mathrm{~min}^{-1}$; linear

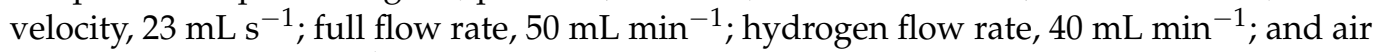

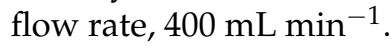

An Optima-17MS GC column (30 m ×0.25 mm, SGE Macherey Nagel, Düren, Germany) was used. The temperature regime was the following: retention for $0.5 \mathrm{~min}$ at $80{ }^{\circ} \mathrm{C}$; heating from $80{ }^{\circ} \mathrm{C}$ to $290{ }^{\circ} \mathrm{C}\left(2{ }^{\circ} \mathrm{C} \mathrm{min}-1\right)$; heating from $290{ }^{\circ} \mathrm{C}$ to $300{ }^{\circ} \mathrm{C}\left(5^{\circ} \mathrm{C} \mathrm{min}{ }^{-1}\right)$; retention for $5 \mathrm{~min}$. at $300{ }^{\circ} \mathrm{C}$; and heating from $300^{\circ} \mathrm{C}$ to $310^{\circ} \mathrm{C}\left(5^{\circ} \mathrm{C} \mathrm{min}{ }^{-1}\right)$.

In the study, all FAs samples were analyzed as two independent replicates, including the whole-sample preparation stage. It was shown that these techniques allow for the correct determination of total FAME content and the analysis of individual FAMEs. The laboratory precision of FAME determinations was estimated by calculating the relative standard deviations (RSD) of the two replicate results from the average value using a degree of freedom number (f) of 22. The homogeneity of variations for selected subgroups was verified using the Fisher and Cochran tests. The repeatability of the technique was characterized by $\mathrm{V}=6 \%$ for total FAME content. The accuracy of the determination of individual $\mathrm{C} 18 \div \mathrm{C} 22$ FAMEs with one to six double bonds was estimated using the "Input-Found" method $(n=2, p=0.95)$ [27].

\section{Results}

The cells were grown for 62 days in microvolume to obtain data on the rate and growth phases of Entomoneis cf. paludosa strain 8.0727-B. The doubling of the cells occurred once every three days. Two weeks after inoculation, the culture was in the exponential growth phase; at the end of the experiment, the culture was at the beginning of the stationary phase (Figure 1). 


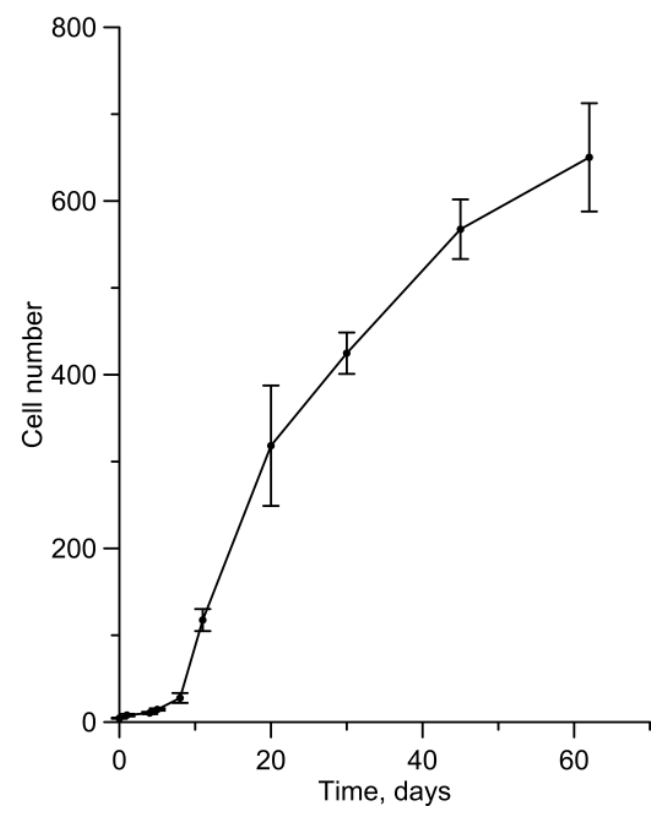

Figure 1. Growth of E. cf. paludosa cells during 62 days.

As revealed by laser scanning confocal microscopy, the cells contained one single flattened chloroplast capable of forming large lobes (Figure 2A,B). When cultured for two weeks, no lipid droplets were observed in the cells after staining with BODIPY 505/515, whereas, after 62 days of cultivation, numerous lipid bodies were observed per cell. These lipid bodies had diameters of 0.3 to $2.15 \mu \mathrm{m}$, adhered to the chloroplasts, and often formed clusters (Figure 2C).
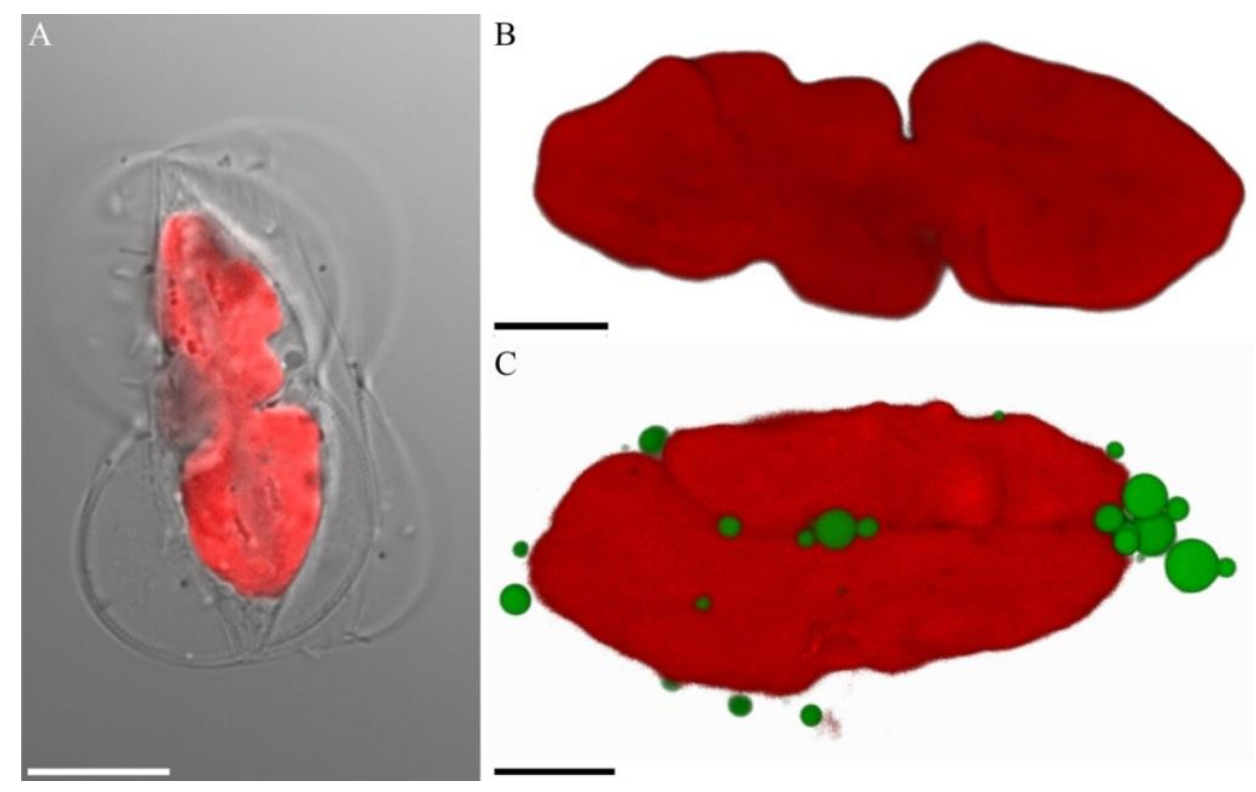

Figure 2. Chloroplasts in the cells of E. cf. paludosa of 14-day culture (A,B) and 62 days of cultivation (C); note lipid bodies stained with BODIPY 505/515 (LSCM). (A)—optical slice; (B,C)—3Dreconstruction. Scale bars: (A) $-100 \mu \mathrm{m} ;(\mathbf{B}, \mathbf{C})-5 \mu \mathrm{m}$.

Transmission electron microscopy revealed that the cells have a pyramidal nucleus adjacent to the chloroplast and surrounded by dictyosomes (Figure 3A). Many small oval mitochondria were located, mainly on the periphery of the cell (Figure 3A). The chloroplasts in the cells of the 14-day culture (Figure 3A,B) contained small plastoglobules $(40-50 \mathrm{~nm})$. The pyrenoid was penetrated with one lamella composed of two thylakoids (Figure 3B); 
in some sections of chloroplasts, heterogeneity of the thylakoid morphology was visible because of the accumulation of single thylakoids near the pyrenoid (Figure 3A).
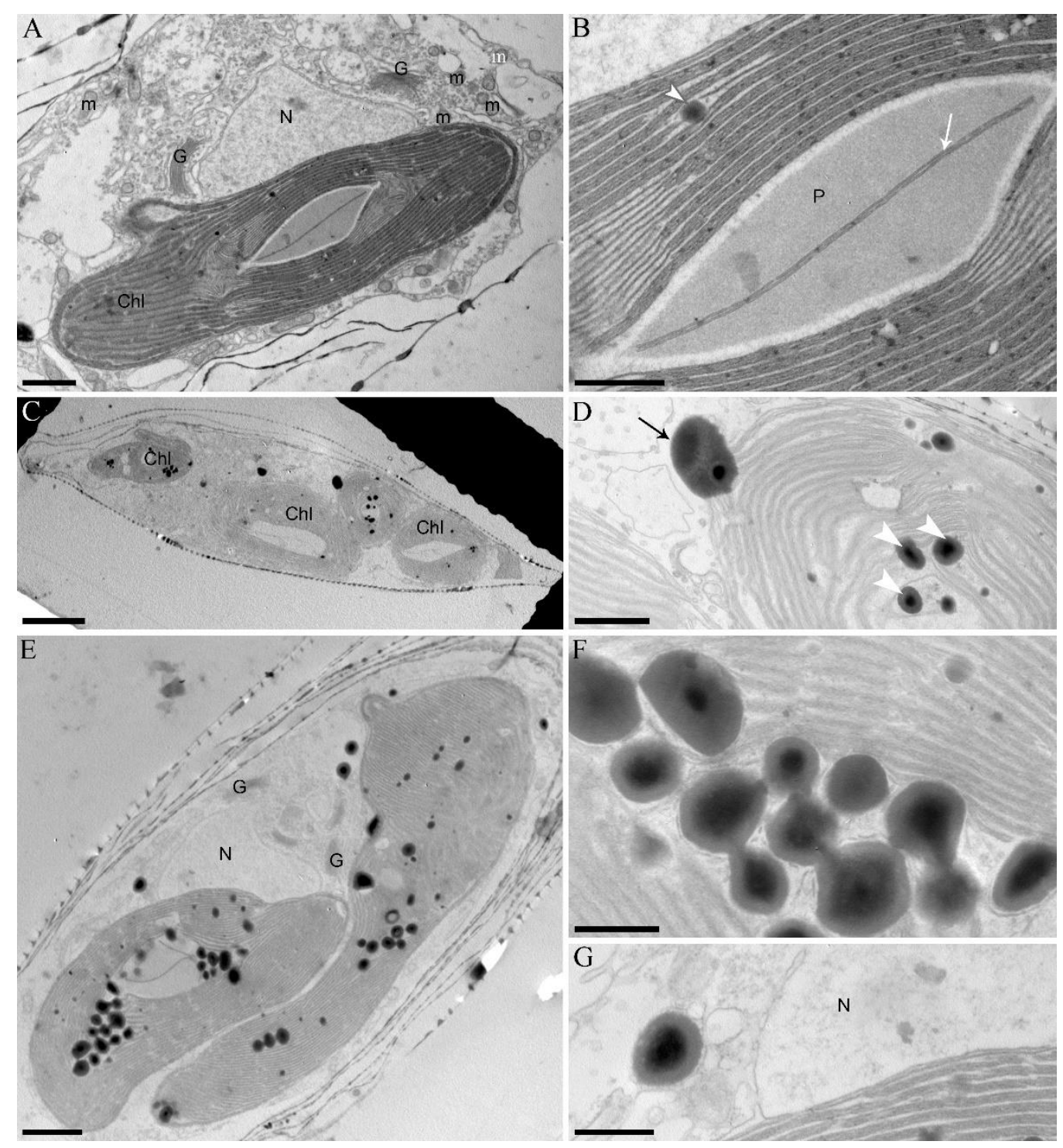

Figure 3. Cell ultrastructure of E. cf. paludosa (TEM). Lipid droplets of cells at exponential (A,B) and stationary $(\mathbf{C}-\mathbf{G})$ stages are marked by short white arrows $(\mathbf{B}, \mathbf{D})$. The lamella penetrating the pyrenoid (B) is marked by long white arrow. The lipid droplet located on the bound of chloroplast and cytoplasm is marked by long black arrow. Legend: Chl—chloroplast; G-Golgi apparatus; $\mathrm{m}-$ mitochondrion; $\mathrm{N}-$ nucleus. Scale bars: $(\mathbf{A}, \mathbf{D})-1 \mu \mathrm{m} ;(\mathbf{B}, \mathbf{F}, \mathbf{G})-500 \mathrm{~nm} ;(\mathbf{C})-5 \mu \mathrm{m} ;(\mathbf{E})-2 \mu \mathrm{m}$.

Clusters of large (up to $1 \mu \mathrm{m}$ in diameter) plastoglobules were found on sections of chloroplasts from the cells of the 62-day culture (Figure $3 \mathrm{C}-\mathrm{G}$ ). In some cases, morphologically similar structures to plastoglobules were observed in the cytoplasm (Figure 3D,G).

The qualitative and quantitative analysis of $E$. cf. paludosa FAs was carried out with a mid-polar column Optima-17MS using GC methods. The peaks of the dominant FAs and the internal standard on the chromatogram are marked (Figure 4A,B). Twenty-one FAME peaks were identified on chromatograms (Table 1). The total FAs in the cell culture varied from $16 \mathrm{mg} \mathrm{g}^{-1}$ (exponential phase) to $40 \mathrm{mg} \mathrm{g}^{-1}$ (stationary phase) of dry weight (d.w.). The average FA content is presented in Table 1. The PUFA percentage of cells in the exponential phase of growth $(\sim 33 \%)$ was higher than the percentage of cells in the stationary phase of growth $(\sim 10 \%)$. 

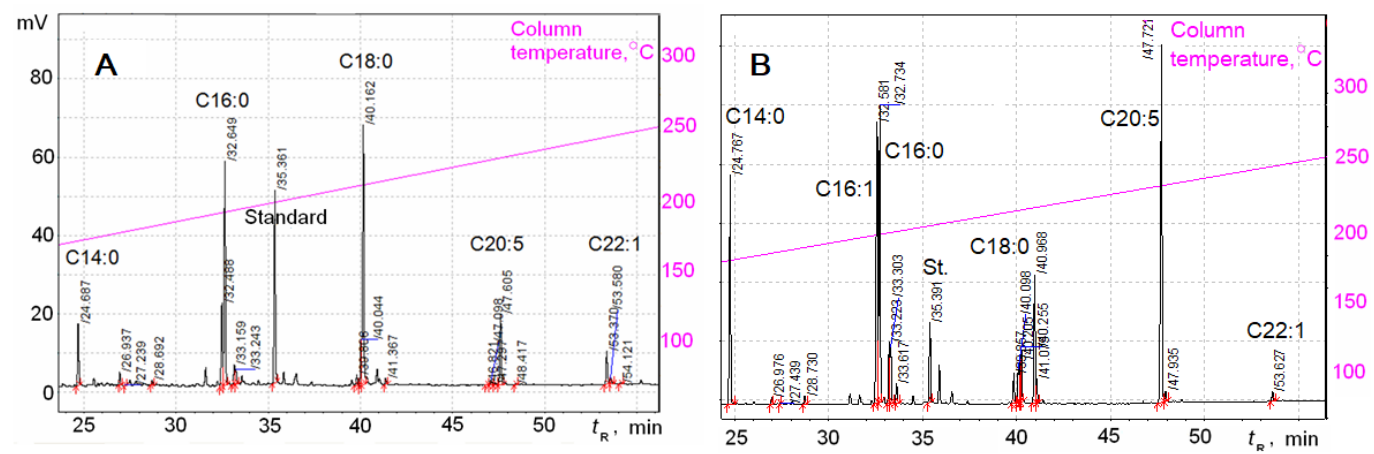

Figure 4. E. cf. paludosa FAMEs extract GC-FID-chromatogram fragment. (A)—stationary phase of growth; (B)—exponential stage.

Table 1. The results of E. cf. paludosa FAMEs analysis by GC-FID.

\begin{tabular}{|c|c|c|c|c|c|c|}
\hline \multirow{3}{*}{ FAs Nos } & \multirow{3}{*}{ FAs Structure } & \multirow{3}{*}{ Retention Times $\left(t_{R}\right)$, Min } & \multicolumn{4}{|c|}{ FAs Content at Two Phases of Growth } \\
\hline & & & \multicolumn{2}{|c|}{ Stationary } & \multicolumn{2}{|c|}{ Exponential } \\
\hline & & & $\mathrm{mg} \mathrm{g}^{-1}$ & $\%$ & $\mathrm{mg} \mathrm{g}^{-1}$ & $\%$ \\
\hline 1 & $\mathrm{C} 12: 0$ & 17.68 & $4.16 \pm 0.4$ & 10.47 & $0.143 \pm 0.013$ & 0.9 \\
\hline 2 & C14:0 & 24.69 & $2.46 \pm 0.22$ & 6.27 & $2.36 \pm 0.21$ & 14.74 \\
\hline 3 & iso-C15:0 & 26.94 & $0.49 \pm 0.04$ & 1.25 & $0.071 \pm 0.006$ & 0.45 \\
\hline 4 & aiso-C15:0 & 27.24 & $0.064 \pm 0.006$ & 0.16 & $\begin{array}{c}0.0047 \pm \\
0.0004\end{array}$ & 0.03 \\
\hline 5 & C15:0 & 28.69 & $0.198 \pm 0.018$ & 0.5 & $0.087 \pm 0.008$ & 0.54 \\
\hline 6 & C16:1 (9) & 32.49 & $3.1 \pm 0.3$ & 7.9 & $3.04 \pm 0.27$ & 19.01 \\
\hline 7 & C16:0 & 32.65 & $10.2 \pm 0.9$ & 26 & $3.25 \pm 0.29$ & 20.33 \\
\hline 8 & $\mathrm{C} 16: 3(n-6,9,12)$ & 33.16 & $0.50 \pm 0.04$ & 1.29 & $0.37 \pm 0.03$ & 2.28 \\
\hline 9 & C16:2 (n-9,12) & 33.24 & $0.37 \pm 0.03$ & 0.95 & $0.32 \pm 0.03$ & 2.02 \\
\hline 10 & C16:4 (n-6,9,12,15) & 33.56 & $0.13 \pm 0.12$ & 0.34 & $0.12 \pm 0.011$ & 0.75 \\
\hline 11 & C18:1 (13) & 39.81 & $0.86 \pm 0.08$ & 2.13 & $0.293 \pm 0.026$ & 1.83 \\
\hline 12 & C18:1 (9) & 40.04 & $1.30 \pm 0.12$ & 3.34 & $0.36 \pm 0.03$ & 2.23 \\
\hline 13 & $\mathrm{C} 18: 2(9,12)$ & 40.06 & n.d. & n.d. & $0.27 \pm 0.024$ & 1.7 \\
\hline 14 & C18:0 & 40.16 & $11.0 \pm 1.0$ & 28.19 & $0.54 \pm 0.05$ & 3.41 \\
\hline 15 & C18:4 $(6,9,12,15)$ & 40.90 & $0.34 \pm 0.03$ & 0.86 & $0.83 \pm 0.07$ & 5.19 \\
\hline 16 & C18:3 $(9,12,15)$ & 41.04 & $0.24 \pm 0.02$ & 0.6 & $0.157 \pm 0.014$ & 1.0 \\
\hline 17 & C20:5 $(5,8,11,14,17)$ & 47.61 & $2.21 \pm 0.20$ & 5.7 & $3.5 \pm 0.3$ & 21.84 \\
\hline 18 & C20:4 $(8,11,14,17)$ & 47.89 & $0.036 \pm 0.003$ & 0.09 & $0.052 \pm 0.005$ & 0.33 \\
\hline 19 & C22:0 & 53.37 & $1.21 \pm 0.11$ & 3.14 & $0.115 \pm 0.010$ & 0.72 \\
\hline 20 & C24:1(9) & 59.48 & $0.190 \pm 0.017$ & 0.19 & $0.063 \pm 0.006$ & 0.39 \\
\hline 21 & C24:0 & 59.60 & $0.125 \pm 0.011$ & 0.33 & $0.054 \pm 0.005$ & 0.43 \\
\hline \multicolumn{3}{|c|}{$\Sigma F A s$} & 39 & & 16 & \\
\hline \multicolumn{3}{|c|}{ Saturated FAs (SFA) } & 30 & 76 & 6.6 & 41 \\
\hline \multicolumn{3}{|c|}{ Monounsaturated FAs (MUFA) } & 5.4 & 14 & 3.8 & 23 \\
\hline \multicolumn{3}{|c|}{ Polyunsaturated FAs (PUFA) } & 3.8 & 10 & 5.3 & 33 \\
\hline
\end{tabular}

\section{Discussion}

Despite the peculiarities of the valve morphology, the cell ultrastructure of the studied species does not have any distinctive features and is typical of most pennate diatoms $[25,28]$. One notable finding was the heterogeneity in the structure of the thylakoids, which can consist of either three or two lamellae. In the latter case, a thylakoid has one short lamella, the length of which does not reach the pyrenoid, which implies that lamellae in the thylakoid in the pyrenoid region are less densely packed. Such a structure is likely important for the functioning of the chloroplast; in Phaeodactylum tricornutum, the segregation of photosystems I and II on thylakoid domains was previously demonstrated using biochemical analysis and immunolocalization [29].

In most cases, TAGs accumulation in the deficiency of nutrients, which is observed during the ageing of the culture, occurs in lipid bodies (or lipid droplets) in the cytoplasm 
of all of the studied diatoms, including E. cf. paludosa and other microalgae [6]. According to recent studies, the lipid bodies of microalgae are not long-term reserves of carbon and energy but temporary reservoirs for a quick response to environmental changes [12]. The stored lipids (mainly TAGs) are used to quickly regenerate microalgae cells when conditions are favorable.

A feature of the ultrastructure of E. cf. paludosa is the increased number and large size of plastoglobules in the chloroplasts of cells during the stationary growth phase, which has not been previously described for diatoms. Interestingly, on ultrathin sections, the morphological features of enlarged plastoglobules are similar to those of lipid bodies in the cytoplasm (Figure 3D,F,G). In previous publications, such ultrastructural changes were not observed in any of the species of microalgae [15]. A small number of works on morphological changes in lipid accumulations in the various cell regions are associated, in our opinion, with the uniformity of such changes. As mentioned above, the most common cell morphological changes in response to stressful conditions, including nutrient deficiency, is an increase in the size and number of lipid droplets in the cytoplasm [6]. For the first time, in our work, we were able to show that nutrient deficiency can also cause a dramatic increase in plastoglobules in chloroplasts. These data clearly demonstrate the relationship between cell and chloroplast metabolism at the level of lipid metabolism.

Currently, there are a number of studies and reviews on the lipid accumulation in diatoms under different growth conditions $[4,12]$. In some cases, data are given on the total lipid content, including pigments, TAGs, membrane lipids, free fatty acids (Table 2), and other lipid substances, which can significantly increase or decrease depending on lighting conditions and the presence of nitrates $[11,30,31]$. The more common and clear evidence of the involvement of TAGs in the response of microalgae cells (not only diatoms) to stress is a change in the composition of FAs (Table 2), which can change significantly with nutrient deficiencies and the growth stage of a laboratory culture. It is known that microalgae, and especially diatoms, are the primary producers of a wide range of FAs, including saturated FAs (SFAs); monounsaturated FAs (MUFAs); and essential polyunsaturated FAs (PUFAs), such as eicosatetraenoic $\mathrm{C} 20: 4 \omega-6$, eicosapentaenoic $\mathrm{C} 20: 5 \omega-3$, and docosahexaenoic C22: $6 \omega-3$, among others, where $\omega$ characterizes the double bond position from the tail of the alkyl chain of the molecule [32]. These FAs significantly affect the functioning and energy potential of cells [33,34].

This work demonstrates that the investigated strain of $E$. cf. paludosa has a high potential for the synthesis of FAs, including SFA. The culture E. cf. paludosa in the stationary growth phase can be a source of biofuel, synthesizing $~ 80 \%$ of saturated fatty acids, and $E$. cf. paludosa produces a number of valuable polyunsaturated essential $\omega-3$ acids, including $\alpha$-linolenic (C18: 3), octadecatetraenoic (C18: 4), eicosatetraenoic (C20: 4), and eicosapentaenoic (C20: 5) FAs. Interestingly, the studied E. cf. paludosa strain is distinguished by the maximum content of essential eicosapentaenoic acid along with the marine diatoms Odontella aurita, Attheya longicornis, Porosira glacialis (Table 2). This acid provides antimicrobial [35] and antitumor activity [36]. E. cf. paludosa can be considered a model organism in studies of the structure, chemical composition, functions of plastoglobules, and the relationship in the chloroplast and cell TAG metabolism in diatoms. 
Table 2. Comparison of the fatty acid composition in different species of diatoms.

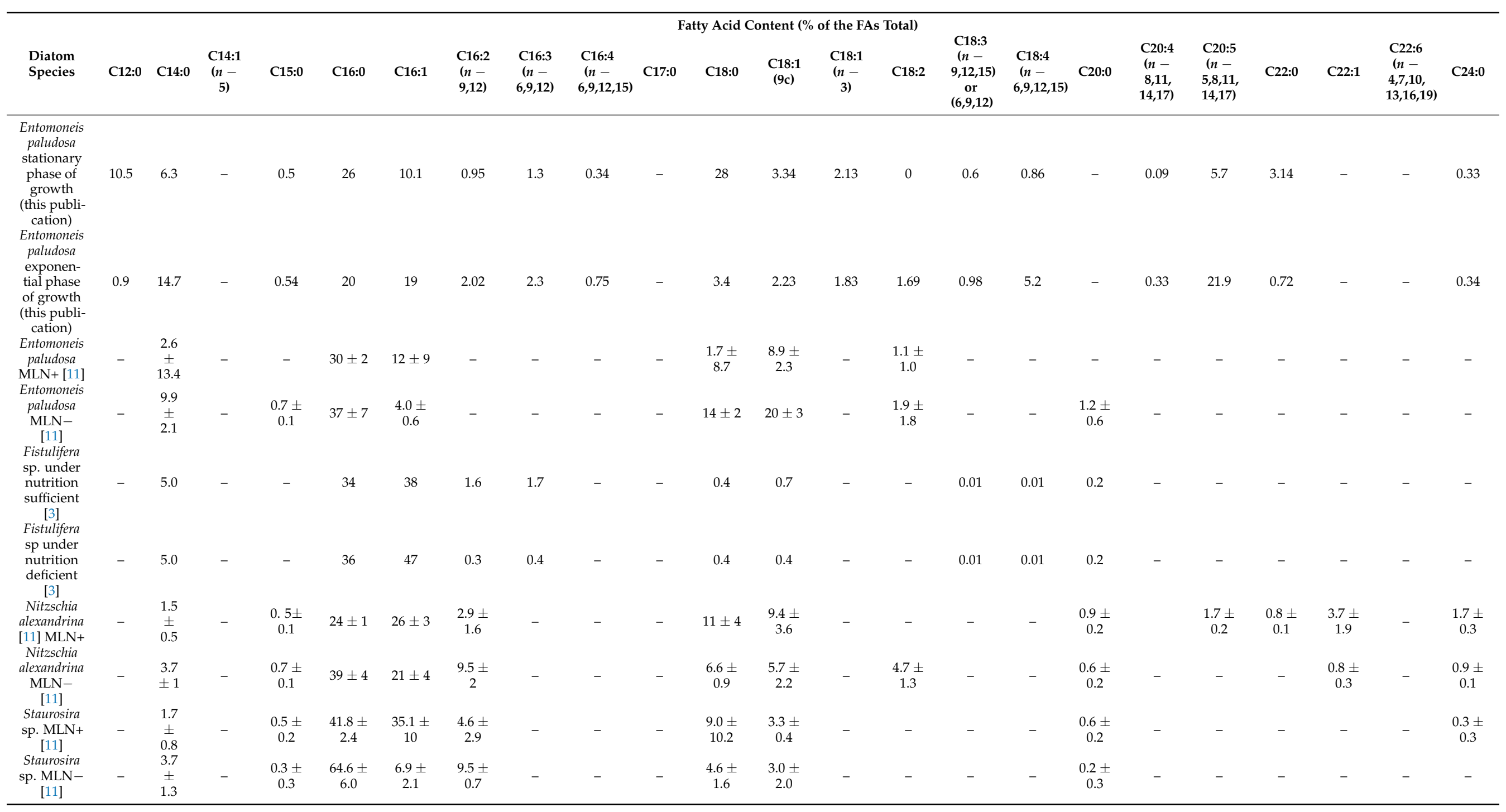


Table 2. Cont.

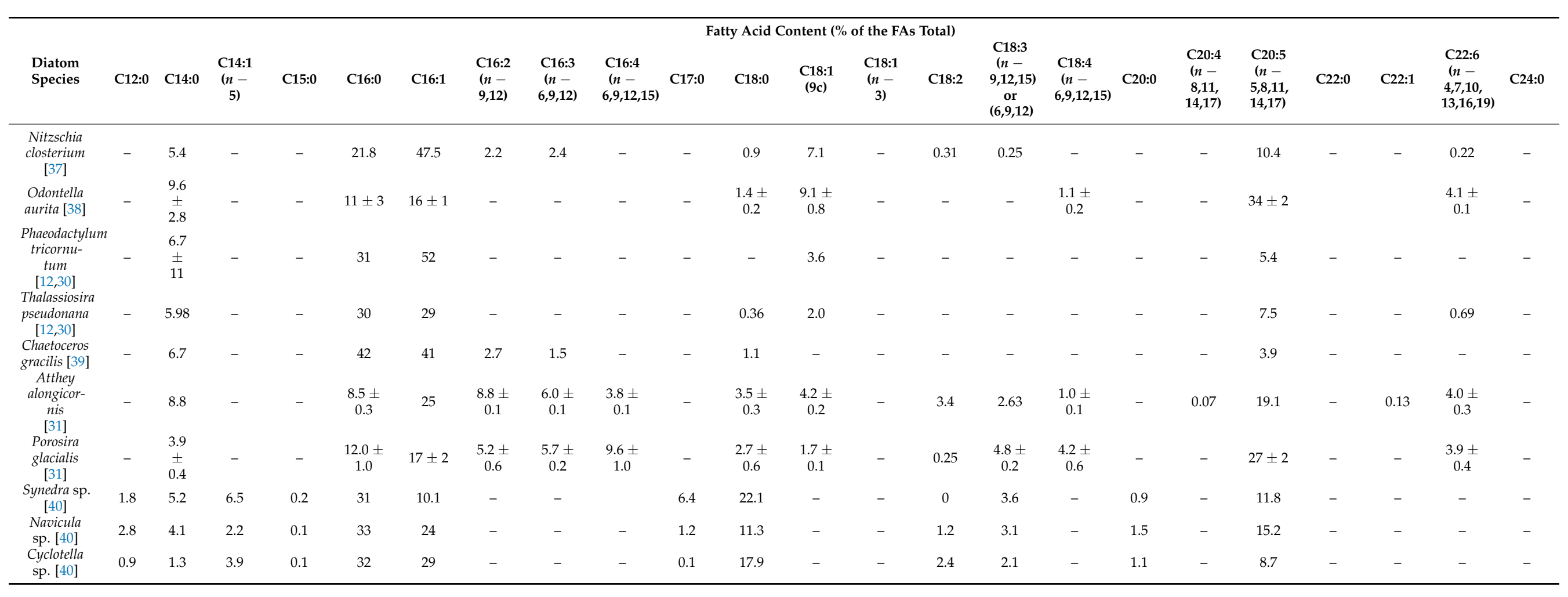


Author Contributions: Conceptualization, Y.B., Y.P., N.D. and Y.L.; methodology, Y.B., Y.P. and A.N.; validation, N.D. and Y.L.; investigation, Y.B., Y.P., E.B. and A.M.; writing-original draft preparation, Y.B.; writing-review and editing, N.D. and Y.L.; visualization, Y.B.; supervision, N.D. and Y.L.; project administration, Y.L.; funding acquisition, Y.L. All authors have read and agreed to the published version of the manuscript.

Funding: This research was funded by State Assignments of Limnological Institute, Siberian Branch of Russian Academy of Sciences, project number 0279-2021-0008 (121032300186-9). Investigated strain was isolated and introduced in a culture thanks to the project number 121032300019-0, Study of Fundamental Physical, Physiological, Biochemical, Reproductive, Population, and Behavioral Characteristics of Marine Hydrobionts funding by the Ministry of Science and Higher Education of The Russian Federation.

Institutional Review Board Statement: Not applicable.

Informed Consent Statement: Not applicable.

Data Availability Statement: Not applicable.

Conflicts of Interest: The authors declare no conflict of interest. The funders had no role in the design of the study; in the collection, analyses, or interpretation of data; in the writing of the manuscript, or in the decision to publish the results.

\section{References}

1. Ragueneau, O.; Treguer, P.; Leynaert, A.; Anderson, R.F.; Brzezinski, M.A.; DeMaster, D.J.; Dugdale, R.C.; Dymond, J.; Fischer, G.; Francois, R.; et al. A Review of the Si cycle in the modern ocean: Recent progress and missing gaps in the application of biogenic opal as a paleoproductivity proxy. Glob. Planet. Chang. 2000, 26, 317-365. [CrossRef]

2. d'Ippolito, G.; Sardo, A.; Paris, D.; Vella, F.M.; Adelfi, M.G.; Botte, P.; Gallo, C.; Fontana, A. Potential of lipid metabolism in marine diatoms for biofuel production. Biotechnol. Biofuels 2015, 8, 28. [CrossRef] [PubMed]

3. Liang, Y.; Maeda, Y.; Yoshino, T.; Matsumoto, M.; Tanaka, T. Profiling of fatty acid methyl esters from the oleaginous diatom Fistulifera sp. strain JPCC DA0580 under nutrition-sufficient and -deficient conditions. J. Appl. Phycol. 2014, 26, 2295-2302. [CrossRef]

4. Zulu, N.N.; Zienkiewicz, K.; Vollheyde, K.; Feussner, I. Current trends to comprehend lipid metabolism in diatoms. Prog. Lipid Res. 2018, 70, 1-16. [CrossRef] [PubMed]

5. Lupette, J.; Jaussaud, A.; Seddiki, K.; Morabito, C.; Brugière, S.; Schaller, H.; Kuntz, M.; Putaux, J.-L.; Jouneau, P.-H.; Rébeillé, F.; et al. The architecture of lipid droplets in the diatom Phaeodactylum tricornutum. Algal Res. 2019, 38, 101415. [CrossRef]

6. Goold, H.; Beisson, F.; Peltier, G.; Li-Beisson, Y. Microalgal lipid droplets: Composition, diversity, biogenesis and functions. Plant Cell Rep. 2015, 34, 545-555. [CrossRef]

7. Zienkiewicz, K.; Du, Z.Y.; Ma, W.; Vollheyde, K.; Benning, C. Stress-induced neutral lipid biosynthesis in microalgae: Molecular, cellular and physiological insights. Biochim. Biophys. Acta 2016, 1861, 1269-1281. [CrossRef]

8. Yang, Z.K.; Niu, Y.F.; Ma, Y.H.; Xue, J.; Zhang, M.H.; Yang, W.D.; Liu, J.S.; Lu, S.H.; Guan, Y.; Li, H.Y. Molecular and cellular mechanisms of neutral lipid accumulation in diatom following nitrogen deprivation. Biotechnol. Biofuels 2013, 6, 67. [CrossRef]

9. Abida, H.; Dolch, L.J.; Meï, C.; Villanova, V.; Conte, M.; Block, M.A.; Finazzi, G.; Bastien, O.; Tirichine, L.; Bowler, C.; et al. Membrane glycerolipid remodeling triggered by nitrogen and phosphorus starvation in Phaeodactylum tricornutum. Plant Physiol. 2015, 167, 118-136. [CrossRef]

10. Smith, S.R.; Gle, C.; Abbriano, R.M.; Traller, J.C.; Davis, A.; Trentacoste, E.; Vernet, M.; Allen, A.E.; Hildebrand, M. Transcript level coordination of carbon pathways during silicon starvation-induced lipid accumulation in the diatom Thalassiosira pseudonana. New Phytol. 2016, 210, 890-904. [CrossRef]

11. Cointet, E.; Wielgosz-Collin, G.; Bougaran, G.; Rabesaotra, V.; Gonçalves, O.; Méléder, V. Effects of light and nitrogen availability on photosynthetic efficiency and fatty acid content of three original benthic diatom strains. PLOS ONE 2019, 14, e0224701. [CrossRef] [PubMed]

12. Maeda, Y.; Nojima, D.; Yoshino, T.; Tanaka, T. Structure and properties of oil bodies in diatoms. Phil. Trans. R. Soc. B 2017, 372, 20160408. [CrossRef] [PubMed]

13. Greenwood, A.D.; Leech, R.M.; Williams, J.P. The osmiophilic globules of chloroplasts: I. Osmiophilic globules as a normal component of chloroplasts and their iso-lation and composition in Viciafaba L. Biochim. Biophys. Acta 1963, 78, 148-162. [CrossRef]

14. Austin, J.R.I.; Frost, E.; Vidi, P.-A.; Kessler, F.; Staehelin, L.A. Plastoglobules are lipoprotein subcompartments of the chloroplast that are permanently coupled to thylakoid membranes and contain biosynthetic enzymes. Plant Cell 2006, 18, 1693-1703. [CrossRef]

15. Bréhélin, C.; Kessler, F.; Van Wijk, K.J. Plastoglobules: Versatile lipoprotein particles in plastids. Trends Plant Sci. 2007, 12, 260-266. [CrossRef] 
16. Piller, E.L.; Abraham, M.; Dormann, P.; Kessler, F.; Besagni, C. Plastid lipid droplets at the crossroads of prenylquinone metabolism. J. Exp. Bot. 2012, 63, 1609-1618. [CrossRef]

17. Rottet, S.; Besagni, C.; Kessler, F. The role of plastoglobules in thylakoid lipid remodeling during plant development. Biochim. Biophys. Acta 2015, 1847, 889-899. [CrossRef]

18. Round, F.; Crawford, R.; Mann, D. The diatoms: Biology and Morphology of the Genera; Cambridge University Press: Bath, UK, 1990.

19. Lohscheider, J.N.; Bártulos, C.R. Plastoglobules in algae: A comprehensive comparative study of the presence of major structural and functional components in complex plastids. Mar. Genom. 2016, 28, 127-136. [CrossRef]

20. Podunay, Y.A.; Davidovich, N.A.; Davidovich, O.I.; Witkowski, A.; Gastineau, R.; Solak, C.N. The sexual reproduction and life cycle of the pennate diatom Entomoneis cf. paludosa (W. Smith) Reimer (Bacillariophyta). Russ. J. Mar. Biol. 2021, 47, 19-28. [CrossRef]

21. Davidovich, N.A.; Davidovich, O.I.; Podunay, Y.A. Diatom culture collection of the Karadag scientific station (Crimea). Mar. Biol. J. 2017, 2, 18-28. [CrossRef]

22. Andersen, R.A.; Berges, J.A.; Harrison, P.J.; Watanabe, M.M. Appendix A-Recipes for Freshwater and Seawater Media. In Algal Culturing Techniques; Elsevier: Amsterdam, The Netherlands, 2005; pp. 429-538.

23. Polyakova, S.L.; Davidovich, O.I.; Podunai, Y.A.; Davidovich, N.A. Modification of the ESAW culture medium used for cultivation of marine diatoms. Morsk. Biol. Zhurnal 2018, 3, 73-80. [CrossRef]

24. Safonova, T.A.; Aslamov, I.A.; Basharina, T.N.; Chenski, A.G.; Vereschagin, A.L.; Glyzina, O.Y.; Grachev, M.A. Cultivation and automatic counting of diatom algae cells in multi-well plastic plates. Diatom Res. 2007, 22, 189-195. [CrossRef]

25. Bedoshvili, Y.D.; Likhoshway, Y.V. The cell ultrastructure of diatoms-Implications for phylogeny? In The Transmission Electron Microscope; Maaz, K., Ed.; InTech: Rijeka, Chroatia, 2012; pp. 147-160.

26. Nikonova, A.A.; Shishlyannikov, S.M.; Shishlyannikova, T.A.; Avezova, T.N.; Babenko, T.A.; Belykh, O.I.; Glyzina, O.Y.; Obolkin, V.A.; Pavlova, O.N.; Smagunova, A.N.; et al. Determination of free and esterified fatty acids in hydrocoles of different content of polyunsaturated fatty acids by gas-liquid chromatography. J. Anal. Chem. 2020, 75, 1310-1321. [CrossRef]

27. Smagunova, A.N. Metody matematicheskoi statistiki v analiticheskoi khimii. In Methods of Mathematical Statistics in Analytical Chemistry; Gosudarstvennyi Universitet: Rostov-na-Donu, Russia, 2008. (In Russian)

28. Bedoshvili, Y.D.; Popkova, T.P.; Likhoshway, Y.V. Chloroplast structure of diatoms of different classes. Cell Tissue Biol. 2009, 3, 297-310. [CrossRef]

29. Flori, S.; Jouneau, P.H.; Bailleul, B.; Gallet, B.; Estrozi, L.F.; Moriscot, C.; Bastien, O.; Eicke, S.; Schober, A.; Bártulos, C.R.; et al. Plastid thylakoid architecture optimizes photosynthesis in diatoms. Nat. Commun. 2017, 8, 15885. [CrossRef] [PubMed]

30. Tonon, T.; Harvey, D.; Larson, T.R.; Graham, I.A. Long chain polyunsaturated fatty acid production and partitioning to triacylglycerols in four microalgae. Phytochemistry 2002, 61, 15-24. [CrossRef]

31. Artamonova, E.Y.; Vasskog, T.; Eilertsen, H.C. Lipid content and fatty acid composition of Porosira glacialis and Attheya longicornis in response to carbon dioxide $\left(\mathrm{CO}_{2}\right)$ aeration. PLoS ONE 2017, 12, e0177703. [CrossRef] [PubMed]

32. Budge, S.M.; Parrish, C.C.; McKenzie, C.H. Fatty acid composition of phytoplankton, settling particulate matter and sediments at a sheltered bivalve aquaculture site. Mar. Chem. 2001, 76, 285-303. [CrossRef]

33. Abedi, E.; Sahari, A.M. Long-chain polyunsaturated fatty acid sources and evaluation of their nutrition and functional properties. Review. Food Sci. Nutr. 2014, 2, 443-463. [CrossRef] [PubMed]

34. Parrish, C.C. Essential fatty acids in aquatic food webs. In Lipids in Aquatic Ecosystems; Arts, M.T., Brett, M.T., Kainz, M., Eds.; Springer: New York, NY, USA, 2009; pp. 309-326. [CrossRef]

35. Le, P.N.T.; Desbois, A.P. Antibacterial effect of eicosapentaenoic acid against Bacillus cereus and Staphylococcus aureus: Killing kinetics, selection for resistance, and potential cellular target. Mar. Drugs 2017, 15, 334. [CrossRef] [PubMed]

36. Yi, Z.; Xu, M.; Di, X.; Brynjolfsson, S.; Fu, W. Exploring valuable lipids in diatoms. Front. Mar. Sci. 2017, 4, 29. [CrossRef]

37. Su, X.; Xu, J.; Yan, X.; Zhao, P.; Chen, J.; Zhou, C.; Zhao, F.; Li, S. Lipidomic changes during different growth stages of Nitzschia closterium f. minutissima. Metabolomics 2013, 9, 300-310. [CrossRef]

38. Pasquet, V.; Ulmann, L.; Mimouni, V.; Guihéneuf, F.; Jacquette, B.; Morant-Manceau, A.; Tremblin, G. Fatty acids profile and temperature in the cultured marine diatom Odontella aurita. J. Appl. Phycol. 2014, 26, 2265-2271. [CrossRef]

39. Tokushima, H.; Inoue-Kashino, N.; Nakazato, Y.; Masuda, A.; Ifuku, K.; Kashino, Y. Advantageous characteristics of the diatom Chaetoceros gracilis as a sustainable biofuel producer. Biotechnol. Biofuels 2016, 9, 235. [CrossRef] [PubMed]

40. Li, X.; Marella, T.K.; Tao, L.; Li, R.; Tiwari, A.; Li, G. Optimization of growth conditions and fatty acid analysis for three freshwater diatom isolates. Phycol. Res. 2017, 65, 177-187. [CrossRef] 